\title{
Nærvær og fravær
}

\section{Høsten 2016 innføres det nye fra-} værsregler i skolen. Elevene vil da trenge legeerklæring ved fravær av helsegrunner. Det kan bli utfordrende for både legene, foreldrene og ungdommene selv.

Jeg har stor respekt for fastleger. Min heter Ole og er en god, gammel bekjent. Det er en fin kombinasjon, pasient og venn, og jeg føler meg godt ivaretatt. Som så mange andre går jeg til ham med visse mellomrom og sjekker kroppens tilstand.

På vei til disse konsultasjonene kjenner jeg på at han og jeg har noen jobbmessige likheter. For mange har sagt til meg at de har kjent litt stress og hjertebank når de kommer inn på «rektors kontor». Og slik kjenner jeg det også når jeg sitter i pasientstolen - litt anspent og litt høyere puls.

Derfor må blodtrykket måles flere ganger. «Sett deg godt til rette og pust ut», får jeg høre, og til slutt havner vi heldigvis på normalen på tredje måling.

Ole legger inn en liten slakk i tiden, slik at vi får tatt oss en prat og oppdatert hverandre på felles kjente. Men jeg kjenner på at jeg ikke kan drøye praten særlig lenge. Til det er det for mange som sitter på venteværelset. De eldste leser utslitte magasiner og de yngre sitter med mobilen og alle gjør det man skal gjøre på et venteværelse de venter. På legen. Alle de som venter, har et problem som legen skal ta del i og for- søke å løse. Forventningene til legen er store. Det er her min store respekt for fastlegene ligger.

Også i min jobb som rektor møter jeg fastleger, både fastlegene til elevene og fastlegene til de ansatte. Igjen forsterkes inntrykket av legenes sterke engasjement for sine pasienter. Og så merker vi at for legen er tid en knapphetsressurs.

Alt dette har jeg i bakhodet når jeg skal forholde meg til de nye fraværsreglene som skal innføres i skolen fra skolestart høsten 2016. Reglene er innført for at man skal forhindre skulking. Altså er hensikten god.

I korte trekk går reglene ut på at dersom en elev har et fravær på mer enn $10 \%$ i et fag, vil de ikke få karakter i faget dersom fraværet ikke er dokumentert. Altså er det slik at dersom fraværet har helsemessige årsaker, telles det ikke med dersom det er dokumentert. I reglene står det: «Den som dokumenterer må ha kompetanse til å vurdere fraværsgrunnen. Det vil si at det kreves legeerklæring for fravær av helsegrunner.» Det holder altså ikke at foresatte skriver: «Per har vært fraværende i to dager grunnet omgangssyke.»Per skal ha legeerklæring.

Så vidt jeg vet, kan ikke leger skrive ut erklæring for noe som har vært, derfor må man komme mens man er syk. Er dette riktig, får jeg opp noen pussige bilder av Per med nylig unnfanget omgangssyke på venteværelset. På sykdommens dag 1 . Antagelig i stolen rett ved siden av toalettet.
Spøk til side. Så kan man si: Er ikke 10\% en romslig kvote med udokumentert fravær? Jo da, i de fleste fag er det slik. Men i videregående skole er det slik at vi har flere totimersfag. Dette utgjør 75 timer i løpet av et skoleår. Slike fag leses i økter på to sammenhengende timer. Det vil si at dersom man er fraværende to ganger i høstsemesteret og to ganger på våren, er man godt over fraværsgrensen. Det vil igjen kunne bety at eleven ikke får vitnemål. Dette vil få store konsekvenser, først og fremst for eleven, men også for samfunnet.

Og merk dere: Denne fraværsgrensen er ikke veiledende, den er absolutt. Derfor, hvis fraværet skyldes helsemessige forhold, vil både foresatte og elever gjøre det de kan for å få dokumentert dette. Altså vil de gå til fastlegen.

Kanskje blir det slik at det fra høsten av blir enda flere på venteværelsene. Kanskje blir det slik at tiden blir enda knappere for fastlegene. Vi får vente og se. Men kjære fastleger: Når Per og andre elever kommer og skal ha legeerklæring for omgangssyke, ta pent imot dem. De gjør bare det de må.

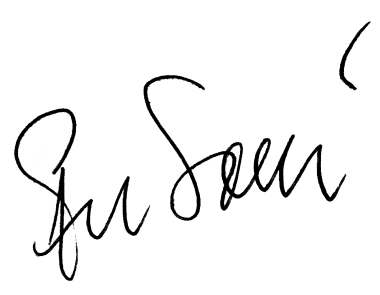

